\title{
An evaluation of extended incubation time with blind subculture of blood cultures in patients with suspected endocarditis
}

\author{
Kevin R Forward MD FRCPC
}

\begin{abstract}
KR Forward. An evaluation of extended incubation time with blind subculture of blood cultures in patients with suspected endocarditis. Can J Infect Dis Med Microbiol 2006;17(3):186-188.
\end{abstract}

BACKGROUND: In a small proportion of patients, bacterial endocarditis is due to organisms that grow slowly and may not be recovered in conventional blood cultures incubated for five days. This has led to recommendations for prolonged incubation and routine subculture of negative cultures.

OBJECTIVE: The above-mentioned approach is evaluated.

METHOD: The microbiology of all blood cultures subjected to prorecovered after five days were evaluated to determine their clinical significance.

RESULTS: In all, 507 blood cultures were handled using an extended incubation and blind subculture protocol. Fifty-three blood cultures in 27 patients were positive. Blood cultures were positive after five days in only five cases; patient outcomes were not affected by the results in any of these cases, although several fastidious organisms (ie, Haemophilus paraphrophilus and Haemophilus parainfluenzae) were recovered in the first five days of incubation.

CONCLUSION: Prolonged incubation and blood subcultures in patients with suspected endocarditis or infections due to fastidious organisms do not represent a wise use of increasingly scarce resources.

Key Words: Blood cultures; Diagnosis; Endocarditis longed incubation and the charts of individuals who had organisms

\section{Une évaluation du temps d'incubation prolongée de sous-cultures à l'aveugle d'analyses sanguines chez des patients atteints d'une endocardite présumée}

\begin{abstract}
HISTORIQUE : Dans une faible proportion de patients, l'endocardite bactérienne est causée par des organismes qui croissent lentement et risquent de ne pas être dépistés dans des cultures sanguines incubées pendant cinq jours. Cette constatation a donné lieu à la recommandation de prolonger le temps d'incubation et de procéder à des sous-cultures systématiques des cultures négatives.

OBJECTIF : La démarche précédente est évaluée.

MÉTHODOLOGIE : On a évalué la microbiologie de toutes les analyses sanguines soumises à une incubation prolongée et le dossier des personnes chez qui on avait dépisté des organismes après la période habituelle de cinq jours, afin de déterminer leur signification clinique.

RÉSULTATS : Dans l'ensemble, 507 analyses sanguines ont été manipulées au moyen d'un protocole d'incubation prolongée et de souscultures à l'aveugle. Cinquante-trois analyses sanguines prélevées chez 27 patients étaient positives. Les analyses sanguines étaient positives après la période de cinq jours dans seulement cinq cas. L'issue de ces patients ne changeait en rien par suite de ces résultats, même si quelques organismes pernicieux (p. ex., Haemophilus paraphrophilus et $H$ parainfluenzae) ont été prélevés dans les cinq premiers jours suivant l'incubation.

CONCLUSIONS : Une incubation prolongée et des sous-cultures sanguines des patients atteints d'une endocardite présumée ou d'une infection causée par des organismes pernicieux ne constituent pas une utilisation judicieuse de ressources de plus en plus rares.
\end{abstract}

('the Centre') laboratory (Halifax, Nova Scotia). The Centre services the Capital District Health Authority, which has a population of 395,000. All regional blood cultures, with the exception of those from the Izaak Walton Killam Health Centre (a children's and women's hospital in Halifax, Nova Scotia), are processed in our laboratory.

slow growing or noncultureable, patients may have received prior antimicrobial therapy, and low-grade bacteremia may result in a very small inoculum. The failure to culture an adequate volume of blood is perhaps the most important reason for falsely negative blood cultures (4). Traditionally, many laboratories have followed the practice of extending the incubation of blood culture bottles from 14 to 21 days to improve recovery rates (2). Expanded protocols require additional resources, occupy valuable space on blood culture instruments, may increase contamination rates and lead to a delayed final report. I evaluated our experience with consecutive blood cultures for suspected endocarditis collected between June 2002 and August 2005 at the Queen Elizabeth II Health Sciences Centre

\section{METHODS}

Specimens were received in BACTEC vials (Becton Dickinson, Canada), either as a single aerobic vial (BACTEC Plus Aerobic/F) or a set (with the addition a BACTEC Standard Anaerobic/F vial). Cultures were continuously monitored on a BACTEC 9240 instrument (Becton Dickinson, Canada). When the IE protocol was requested, the incubation time was extended to 24 days from five days. On day 10, three to five drops of media from each vial were subcultured onto a chocolate agar slope, loosely capped, incubated in $5 \% \mathrm{CO}_{2}$ at $35^{\circ} \mathrm{C}$ and examined daily for 14 days. The vial was returned to the instrument and monitored for a further 14 days. The final report, if negative, was issued on the 24th day.
\end{abstract}

Department of Pathology and Laboratory Medicine, Queen Elizabeth II Health Sciences Centre, Halifax, Nova Scotia

Correspondence: Dr Kevin R Forward, Division of Microbiology, Queen Elizabeth II Health Sciences Centre, 5788 University Avenue, Halifax,

Nova Scotia B3H 1V8. Telephone 902-473-4109, fax 902-473-4432, e-mail kevin.forward@cdha.nshealth.ca

Received for publication March 31, 2006. Accepted May 9, 2006 
TABLE 1

Organisms recovered from blood cultures and subjected to the prolonged incubation protocol

\begin{tabular}{lcc}
\hline & Isolates, $\mathbf{n}$ & Patients, $\mathbf{n}$ \\
\hline $\begin{array}{l}\text { Staphylococcus species } \\
\text { (not Staphylococcus aureus) }\end{array}$ & 24 & 16 \\
Escherichia coli & 9 & \\
S aureus & 8 & 4 \\
Propionibacterium acnes & 2 & 5 \\
Haemophilus parainfluenzae & 2 & 2 \\
Haemophilus paraphrophilus & 2 & 1 \\
Enterococcus species & 4 & 1 \\
Peptococcus anaerobius & 3 & 3 \\
Viridans streptococci & 1 & 1 \\
Streptococcus mutans & 2 & 1 \\
Klebsiella pneumoniae & 1 & 1 \\
Burkholderia cepacia & 1 & 1 \\
Total & 59 & 1 \\
\hline
\end{tabular}

\section{RESULTS}

During the 38-month period, 507 blood cultures were handled using the IE protocol used at the Centre. Fifty-three blood cultures from 27 patients were positive -47 were positive with single isolates, and six had two isolates. The frequency and distribution of the organisms recovered are shown in Table 1.

In five cases, positive blood cultures would not have been recognized if our endocarditis protocol had not been applied. In the remainder, vials were flagged by the instrument as positive within the first five days. Table 2 summarizes the results of blood cultures positive during the extended incubation period. In two cases, single colonies of coagulase-negative staphylococci were recognized on the chocolate agar subculture at 14 and 22 days. One patient had Propionibacterium acnes detected by the instrument on day 14 . One patient had coagulasenegative staphylococci seen on a Gram stain from a vial flagged by the instrument on day 11. In one case, Enterococcus faecalis was detected on day 6 . The same patient had $E$ faecalis in a blood culture collected the day before, which was positive by day 3 .

The majority of isolates were nonfastidious, including 24 coagulase-negative staphylococci, nine Escherichia coli and eight Staphylococcus aureus strains. Several patients had organisms that may be considered more fastidious. One patient had Haemophilus paraphrophilus in two cultures, each of which was flagged positive by the BACTEC instrument on day 1. Another patient had two blood cultures positive on days 1 and 2 for Haemophilus parainfluenzae. A third patient had all three cultures positive on day 3 for Peptostreptococcus anaerobius. A fourth patient had Streptococcus mutans detected on days 2 and 3, and another had a viridans streptococcus recovered after one day of incubation.

\section{DISCUSSION}

In our experience, the prolonged incubation of blood cultures did not positively impact the care of any patient, because no additional cases of IE were diagnosed and no fastidious organisms were detected after day 5. All but one organism detected after day 5 were deemed contaminants. The variety of organisms seen in the study did not reflect the
TABLE 2

\begin{tabular}{|c|c|c|c|c|}
\hline Patient & Isolate & $\begin{array}{l}\text { Day } \\
\text { detected }\end{array}$ & $\begin{array}{l}\text { Detected by } \\
\text { instrument? }\end{array}$ & Observations \\
\hline 1 & $\begin{array}{l}\text { Staphylococcus } \\
\text { species (not } \\
\text { Staphylococcus aureus) }\end{array}$ & 14 & No & $\begin{array}{l}\text { Single colony on } \\
\text { agar subculture, } \\
\text { contaminant }\end{array}$ \\
\hline 2 & $\begin{array}{l}\text { Staphylococcus } \\
\text { species (not } S \text { aureus) }\end{array}$ & 22 & No & $\begin{array}{l}\text { Single colony on } \\
\text { agar subculture, } \\
\text { contaminant }\end{array}$ \\
\hline 3 & $\begin{array}{l}\text { Staphylococcus } \\
\text { species (not } S \text { aureus) }\end{array}$ & s) 11 & Yes & $\begin{array}{l}\text { Flagged by } \\
\text { instrument, } \\
\text { contaminant }\end{array}$ \\
\hline 4 & Enterococcus faecalis & 6 & Yes & $\begin{array}{l}\text { Accompanying } \\
\text { second culture } \\
\text { positive on day } 3\end{array}$ \\
\hline 5 & $\begin{array}{l}\text { Propionibacterium } \\
\text { acnes }\end{array}$ & 14 & Yes & $\begin{array}{l}\text { Flagged by } \\
\text { instrument, } \\
\text { contaminant }\end{array}$ \\
\hline
\end{tabular}

expected distribution of patients with endocarditis. Instead, it appeared to reflect that many patients initially assessed with fever did not have endocarditis, when endocarditis was considered possible, but rather had bacteremia from a variety of sources.

It was not possible to determine the extent to which delayed reporting of negative cultures may have altered decisions relating to the duration of antibiotic treatment or the search for the correct diagnoses. Our experience is similar to that of Varettas et al (5), who also concluded that extended incubation was not productive. Towns and Reller (6) recommended blind subculture of automated IE blood cultures at five days, rather than extending the instrument incubation for two or three weeks. My findings suggest that even this step is not a valuable use of resources. My findings are also consistent with those of Cockerill et al (4) and Baron et al (7). Baron et al (7) found that an extensive protocol (including extended incubation) of blood cultures for endocarditis yielded only three clinically relevant results. Cockerill et al (4) found that all 51 patients with endocarditis who had blood cultures incubated for up to $168 \mathrm{~h}$ were detected within the first five days.

A small proportion of patients with IE have negative blood cultures, despite best efforts to isolate the causative organism. In recent years, there has been increasing success diagnosing culture-negative endocarditis using molecular means, particularly via broad-range polymerase chain reaction assay with primers directed against conserved sequences in the bacterial $16 \mathrm{~S}$ ribosomal RNA gene (8-12). The $16 \mathrm{~S}$ ribosomal polymerase chain reaction assays with subsequent sequencing of the amplicon has been successful in a number of cases of IE due to Haemophilus species (H parainfluenzae, $H$ aphrophilus, $H$ paraphrophilus), Actinobacillus actinomycetemcomitans, Cardiobacterium hominis, Eikenella corrodens, Kingella species (the HACEK group), Tropheryma whipplei and Bartonella species (3). The judicious use of serology in IE cases due to Coxiella burnetii, Bartonella species, Mycoplasma species or Legionella species is often diagnostic $(3,13)$.

These observations suggest that the prolonged incubation and blind subculture of blood cultures in suspected cases of 
IE are unlikely to contribute to patient care. It is suggested that laboratories apply routine practices with much shorter incubation times, and, when three blood cultures are negative, focus on other nonculture-based strategies for the diagnosis of IE.

\section{REFERENCES}

1. Washington JA. The microbiological diagnosis of infective endocarditis. J Antimicrob Chemother 1987;20(Suppl A):29-39.

2. Fowler VG, Sheld WM, Bayer AS. Endocarditis and endovascular infections. In: Gerald L, Mandell JE, Bennett JE, Dolin R, eds. Principles and Practice of Infectious Diseases, 6th edn. Philadelphia: Elsevier Churchill Livingstone, 1995:975-1022.

3. Brouqui P, Raoult D. Endocarditis due to rare and fastidious bacteria. Clin Microbiol Rev 2001;14:177-207.

4. Cockerill FR III, Wilson JW, Vetter EA, et al. Optimal testing parameters for blood cultures. Clin Infect Dis 2004;38:1724-30.

5. Varettas K, Taylor PC, Mukerjee C. Determination of the optimum incubation period of continuously monitored blood cultures from patients with suspected endocarditis or fungaemia. Pathology 2002;34:167-9.

6. Towns ML, Reller LB. Diagnostic methods current best practices and guidelines for isolation of bacteria and fungi in infective endocarditis. Infect Dis Clin North Am 2002:16:363-76.
7. Baron EJ, Scott JD, Tompkins LS. Prolonged incubation and extensive subculturing do not increase recovery of clinically significant microorganisms from standard automated blood cultures. Clin Infect Dis 2005;41:1677-80.

8. Hryniewiecki T, Gzyl A, Augustynowicz E, Rawczynska-Englert I. [Amplification reaction to bacterial DNA for diagnosing infective endocarditis.] Med Dosw Mikrobiol 2002:54:265-72.

9. Rothman RE, Majmudar MD, Kelen DG, et al. Detection of bacteremia in emergency department patients at risk for infective endocarditis using universal $16 \mathrm{~S}$ rRNA primers in a decontaminated polymerase chain reaction assay. J Infect Dis 2002:186:1677-81.

10. Millar B, Moore J, Mallon P, et al. Molecular diagnosis of infective endocarditis - a new Duke's criterion. Scand J Infect Dis 2001:33:673-80.

11. Lisby G, Gutschik E, Durack DT. Molecular methods for diagnosis of infective endocarditis. Infect Dis Clin North Am 2002:16:393-412.

12. Lang S, Watkin RW, Lambert PA, Bonser RS, Littler WA, Elliott TS. Evaluation of PCR in the molecular diagnosis of endocarditis. J Infect 2004:48:269-75.

13. Houpikian P, Raoult D. Diagnostic methods. Current best practices and guidelines for identification of difficult-to-culture pathogens in infective endocarditis. Cardiol Clin 2003:21:207-17. 


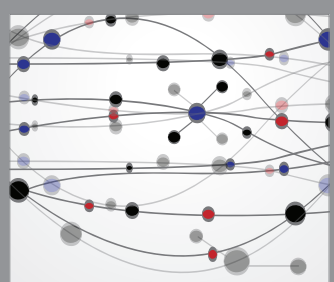

The Scientific World Journal
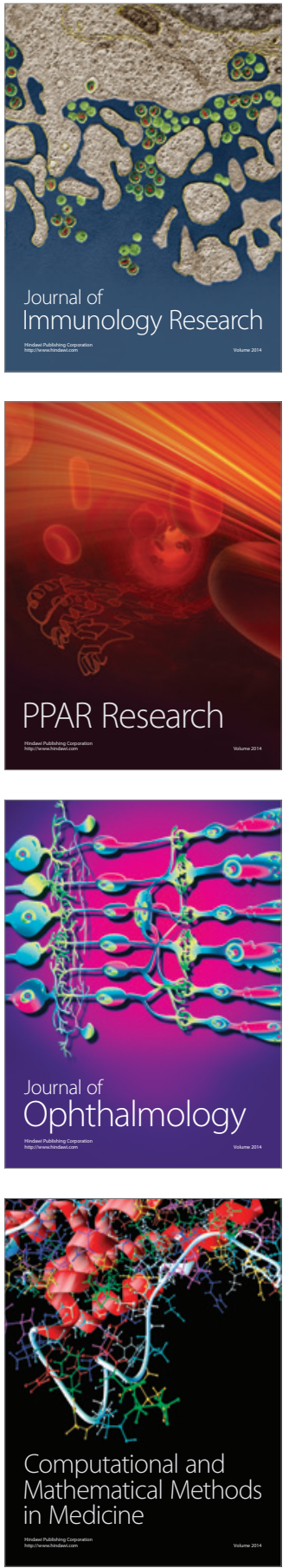

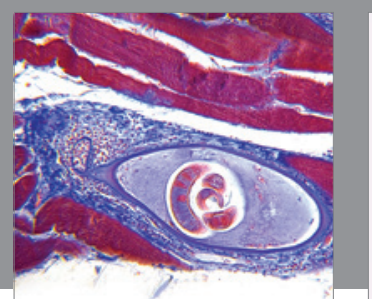

Gastroenterology Research and Practice

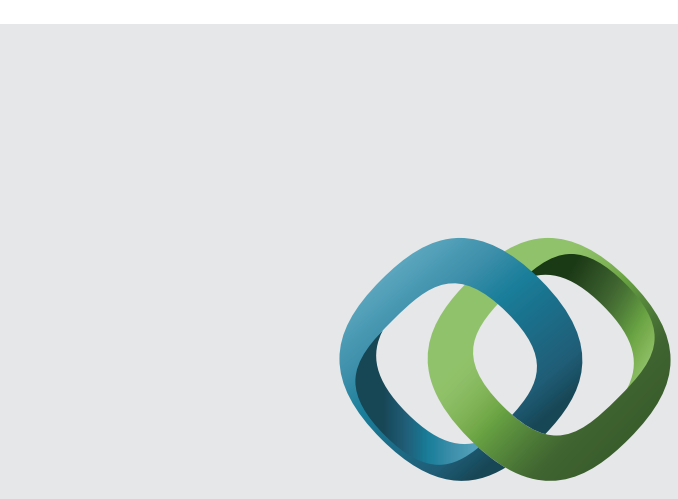

\section{Hindawi}

Submit your manuscripts at

http://www.hindawi.com
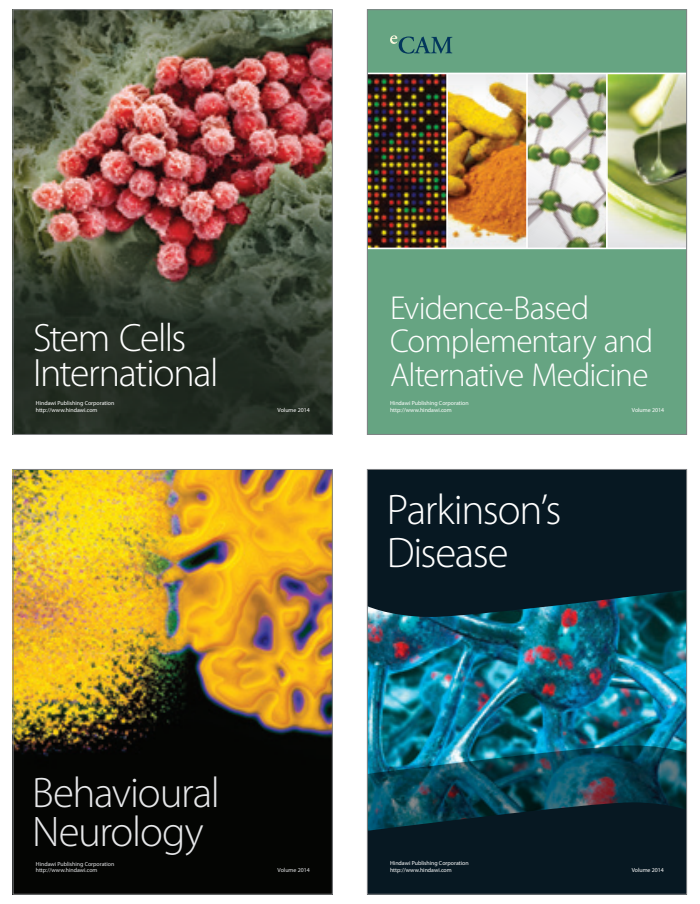
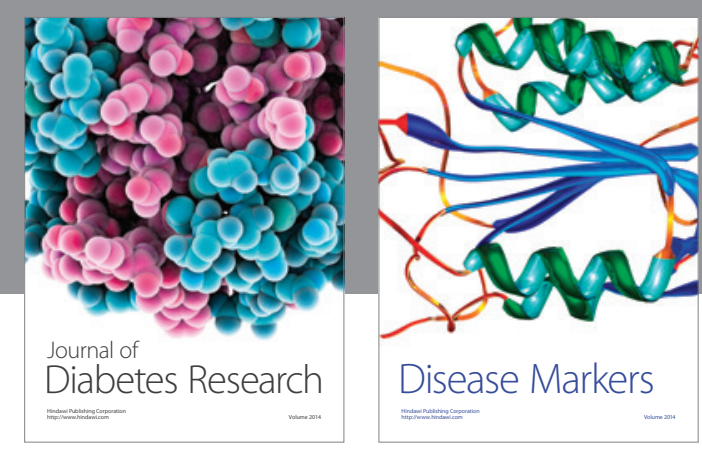

Disease Markers
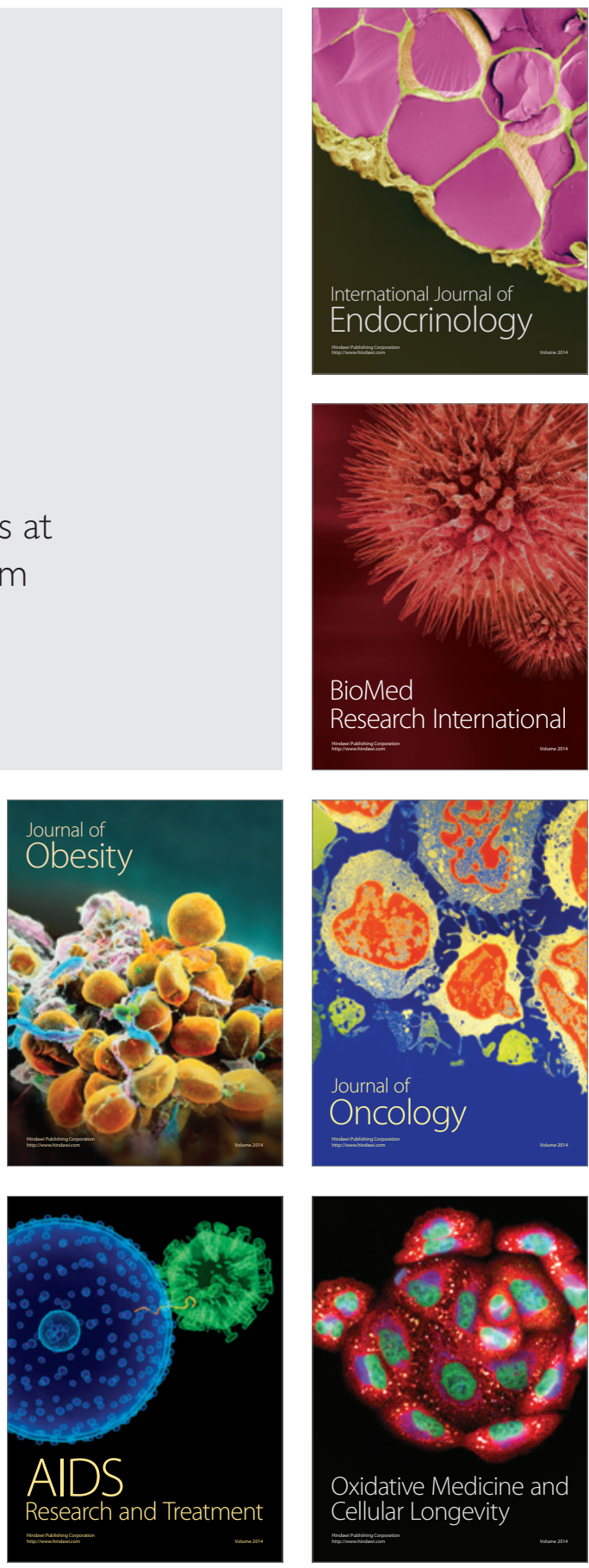